Biogeosciences Discuss., 6, 6147-6177, 2009

www.biogeosciences-discuss.net/6/6147/2009/

(C) Author(s) 2009. This work is distributed under

the Creative Commons Attribution 3.0 License.

\title{
Measurements of soil respiration and simple models dependent on moisture and temperature for an Amazonian southwest tropical forest
}

F. B. Zanchi ${ }^{1,5}$, H. R. da Rocha ${ }^{2}$, H. C. de Freitas ${ }^{2}$, B. Kruijt ${ }^{3}$, M. J. Waterloo ${ }^{1}$, and A. O. Manzi ${ }^{4}$

${ }^{1}$ VU University Amsterdam, De Boelelaan 1085, 1081HV Amsterdam, The Netherlands

${ }^{2}$ Departament of Atmospheric Science-IAG of São Paulo University-USP, Rua do Matão 1226, São Paulo-SP, Brazil

${ }^{3}$ Alterra, Droevendaalsesteeg 3, Wageningen, The Netherlands

${ }^{4}$ Instituto Nacional de Pesquisa da Amazônia-INPA, Av. André Araújo, 2936 Campus 2, CEP: 69060-020, Manaus-AM, Brazil

${ }^{5}$ Universidade Federal do Amazonas-UFAM, Instituto Agricultura e Ambiente - IAA, Rua 29 de Agosto, 786 B. Espírito Santo, CEP: 69800-000, Humaitá-AM, Brazil

Received: 11 May 2009 - Accepted: 2 June 2009 - Published: 24 June 2009

Correspondence to: F. B. Zanchi (faberzanchi@gmail.com)

Soil respiration and simple models in

Amazon forest

F. B. Zanchi et al.

Published by Copernicus Publications on behalf of the European Geosciences Union.

Title Page

Abstract

Introduction

Conclusions

Tables

References

Figures

14

- I

4

Back

Close 


\section{Abstract}

Soil respiration plays a significant role in the carbon cycle of Amazonian tropical forests, although in situ measurements have only been poorly reported and the dependence of soil moisture and soil temperature also weakly understood. This work investigates the

5 temporal variability of soil respiration using field measurements, which also included soil moisture, soil temperature and litterfall, from April 2003 to January 2004, in a southwest Brazilian tropical rainforest near Ji-Paraná, Rondônia. The experimental design deployed five automatic (static, semi-opened) soil chambers connected to an infra-red $\mathrm{CO}_{2}$ gas analyzer. The mean half-hourly soil respiration showed a large scattering 10 from 0.6 to $18.9 \mu \mathrm{mol} \mathrm{CO}_{2} \mathrm{~m}^{-2} \mathrm{~s}^{-1}$ and the average was $8.0 \pm 3.4 \mu \mathrm{mol} \mathrm{CO}_{2} \mathrm{~m}^{-2} \mathrm{~s}^{-1}$. Soil respiration varied seasonally, being lower in the dry season and higher in the wet season, which generally responded positively to the variation of soil moisture and temperature year round. The peak was reached in the dry-to-wet season transition (September), this coincided with increasing sunlight, evapotranspiration and ecosystem productivity. Litterfall processes contributed to meet very favorable conditions for biomass decomposition in early wet season, especially the fresh litter on the forest floor accumulated during the dry season. We attempted to fit three models with the data: the exponential $Q_{10}$ model, the Reichstein model, and the log-soil moisture model. The models do not contradict the scattering of observations, but poorly explain the is longer. The observations suggested an optimum range of soil moisture, between $0.115<\theta \leq 0.25 \mathrm{~m}^{3} \mathrm{~m}^{-3}$, which maximize soil respiration in an approximated non-linear relationship. The $Q_{10}$ coefficient was overestimated and may lead to erroneous calculation at warmer temperatures, which is of concern for global climate models deploying
BGD

$6,6147-6177,2009$

Soil respiration and simple models in Amazon forest

F. B. Zanchi et al.

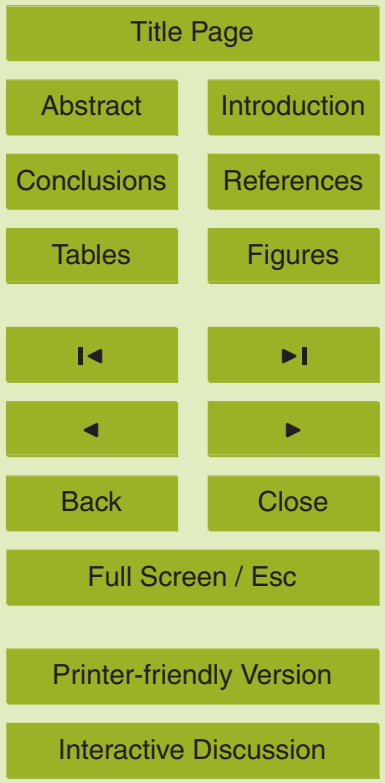




\section{Introduction}

Soil respiration processes play an important role on the carbon cycle of Amazonian forests, which interacts with the water (Richey et al., 2002) and energy fluxes on the spatial and seasonal scales (von Randow et al., 2004), and helps to promote the cou5 pling with the climate (Betts et al., 2004; Saleska et al., 2009). Various authors suggest that soil emissions are between $60-80 \%$ of the total primary production (Meir et al., 1996; Davidson et al., 1998; Janssens et al., 2001). The ability to estimate the carbon budget of the Amazon basin shall improve by reconciling various estimates of the net primary productivity and the heterotrophic sources over tropical terra firme forests, which includes measurements of micrometeorological towers (Saleska et al., 2003; de Araújo et al., 2002; Goulden et al., 2004), soil respiration chambers (Davidson et al., 2000; Sotta et al., 2004; Buchmann et al., 1997; Salimon et al., 2004), remote sensing and aircraft measurements. While measurements of soil respiration in Amazonia have been poorly reported and constrained by spatial variability, simple soil $\mathrm{CO}_{2}$ ef-

15 flux models are enable to show the dependence of the climate and integration with situ measurements (Meir et al., 1996; Davidson et al., 2000), as well as contribute to improve description of land surface parameterization used in climate studies to predict the effects of Amazonian deforestation. Soil respiration measurements are essential to get both a reliable understanding of the driving forces of soil processes and an estimate of the sensitivities of the model formulations to eliminate uncertainties. There is a broad consensus about the necessity to validate model results to observations in tropical region, because of the strong climate anomalies and different local variables forcing. However, field research, especially in Amazonia, is still not exactly in pace with modelling. Some authors defined models of soil respiration as a function of soil temperature and proposed a functional relationship for a particular ecosystem (Lloyd and Taylor, 1994; Davidson et al., 1998; Janssens et al., 2003). The amount of heterotrophic or root respiration in the soil is not only controlled by temperature, but by many other factors, such as soil moisture (Howard and Howard, 1993; Davidson et al.,
BGD

$6,6147-6177,2009$

Soil respiration and simple models in Amazon forest

F. B. Zanchi et al.

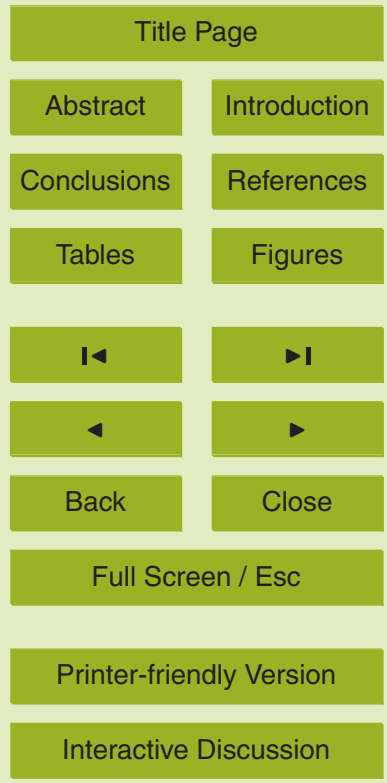

6149 
1998; Irvine and Law, 2002; Janssens et al., 2003; Raich et al., 2002; Reichstein et al., 2003), soil minerals, chemical properties of leaf and root activities of the macrofauna and microfauna (Liski and Westma, 1997; Giardina and Ryan, 2000). Some authors showed some influence of the annual variation of litterfall in the soil respiration (Re5 ichstein et al., 2003; Salimon et al., 2004; Valentini et al., 2008), while others show the $Q_{10}$ parameter $\left(Q_{10}\right.$ is the relative change in respiration with a temperature change of $10^{\circ} \mathrm{C}$ ), can decrease when soil temperature increases (Howard and Howard, 1993; Lloyd and Taylor, 1994; Janssens and Pilegaard, 2003), because the soil respiration also depends on soil moisture conditions. This can be explained by Linn and Doran 10 (1984), the author found that under very dry soil conditions, the substrate diffusion through water films (around soil particles) to microbial active cells is limited. In contrast, under very wet soil conditions, oxygen diffusion may inhibit the gas production, and the diffusion through pore spaces to the atmosphere is limited (Skopp et al., 1990; Davidson, 1993). This non-linear dependence can be avoided when the analysis is restricted to a specific interval of temperature and soil moisture. Lloyd and Taylor (1994) reported that the fits of the $Q_{10}$ factor in the models can systematically underestimate the soil respiration for low temperatures and overestimate it for high temperatures. The ecosystem respiration in different Amazonian forests do not show a similar dependence on the soil moisture. For example, in eastern Amazonia (Santarém), respiration appeared to decline in the whole dry season, which indicates the likely water limitation for such well-drained upland sites during about 4-5 months, despite the increasing litterfall in the early dry season (Keller et al., 2004; Goulden et al., 2004; Saleska et al., 2009). Alternatively, canopy photosynthesis appeared to increase from the middle dry season on, due to a combination of increasing sunlight, green-leaf flush and deep root activity (Saleska et al., 2003; Goulden et al., 2004; da Rocha et al., 2004). Still in eastern Amazonia forests, drought-controlled experiments on sandy soils, in Caxiuana, reduced soil respiration (Sotta et al., 2004), while drought on clay soils in Santarém have not induced substantial changes (Davidson et al., 2008). Differently, in central Amazonia, Manaus, a region dominated by a mosaic of plateaus, and valleys where

BGD

6, 6147-6177, 2009

Soil respiration and simple models in Amazon forest

F. B. Zanchi et al.

Title Page

Abstract

Introduction

Conclusions

Tables

References

Figures

14

4

Back

Close

Full Screen / Esc

Printer-friendly Version

Interactive Discussion 
soils saturate during most of the year, the relationship of soil respiration with soil moisture was negative (Chambers et al., 2004), with higher respiration over the plateaus than in the valleys. In this study we deployed a set of automatic soil chambers, to measure half-hourly soil respiration during 10 months in a southwestern tropical forest

5 in Amazonia, to investigate the diurnal and seasonal patterns, and how simple models dependent on soil moisture and soil temperature help to explain the soil respiration.

\section{Materials and methods}

\subsection{Study area and climate}

The study area was at Fazenda Itapirema, a ranchland placed in south-west Amazonia $10 \quad\left(10^{\circ} 55,60^{\prime} \mathrm{S}\right.$ and $\left.62^{\circ} 01,266^{\prime} \mathrm{W}\right), 15 \mathrm{~km}$ distant from Ji-Paraná city, state of Rondônia, Brazil, bordered by the Urupá's River (162 m a.s.l.). The measurements were made in a pristine tropical forest fragment, of about $500 \mathrm{~m} \times 650 \mathrm{~m}$ size surrounded by a 20 years secondary forest and pasture. The height of the trees varied from 25 to $30 \mathrm{~m}$, with crown diameter of 10 to $15 \mathrm{~m}$, and many palm trees Orbignya martiana (local name, Babaçus). The mean annual precipitation is $2000 \mathrm{~mm}$, and the wet season is defined between September to April. During the dry season, coincident with the winter, the rainfall is often below $20 \mathrm{~mm}$, with monthly average air temperature varying from $24^{\circ} \mathrm{C}$ (in July) to $27^{\circ} \mathrm{C}$ (in October) (da Rocha et al., 2009). The regional weather is often marked by two or three cold events ("friagens"), usually between July and August, due to the influence of large scale cold fronts, which make the temperature falls to $\sim 10^{\circ} \mathrm{C}$ during 1 to 3 days (Culf et al., 1996). The winter is drier, and the specific humidity varies from $11.9 \mathrm{~g} \mathrm{~kg}^{-1}$ in July to $17.2 \mathrm{~g} \mathrm{~kg}^{-1}$ in December (Culf et al., 1996; von Randow et al., 2004). The soil in the study area is an Oxisol, which in general shows contents of $58 \%$ of sand, $33 \%$ of clay and $9 \%$ of silt for the first $15-20 \mathrm{~cm}$ in the region (Ballester et al., 25 2003).

BGD

$6,6147-6177,2009$

Soil respiration and simple models in Amazon forest

F. B. Zanchi et al.

Title Page

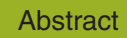

Introduction

Conclusions

Tables

References

Figures

14

$>$ I

4

Back

Close

Full Screen / Esc

Printer-friendly Version

Interactive Discussion 


\subsection{Soil respiration measurements}

The system with the automatic chambers was assembled at the University of São Paulo, designed with five chamber (C1, C2, . .C5) unities (16.4I each), static, semiopened, with a closed-dynamic circuit. The chambers had fixed collars, inserted to

$54 \mathrm{~cm}$ depth in the soil. The closed cycle used a suction air pump that operated at $4 \mathrm{I} \mathrm{min}^{-1}$ in each chamber's headspace, which circulated the air into and out of the gas analyser. For each individual chamber, the air $\mathrm{CO}_{2}$ concentration was measured by an infrared gas analyzer (Ciras-SC, PP Systems, Hitchin, UK), connected to 2 sets of 10 pneumatic valves (Clippard, USA), and recorded in a datalogger (CR10X, Camp10 bell Sci., USA) every $5 \mathrm{~s}$ during $4 \mathrm{~min}$ ( 48 measures). Each chamber was left opened at about $45^{\circ}$ using individual electrical rotor with a cord and pulley. The record was initiated after the chamber was automatically closed. After 4 min the tubes were allowed to flush during $2 \mathrm{~min}$, in order to move to next unity. The entire set of chambers spent $30 \mathrm{~min}$, and restarted immediately after. The mean $\mathrm{CO}_{2}$ variation during each 15 event (4 min) was calculated with the estimate of the linear regression of the $\mathrm{CO}_{2}$ concentration over time time $\left(\frac{\Delta c}{\Delta t}\right)$, which excluded the first 10 samples (or $50 \mathrm{~s}$ ) to prevent spurious influences during the closure. The soil respiration was calculated as:

$R_{s}=\frac{\Delta c}{\Delta t}\left(\frac{P}{T_{\text {soil }} * R}\right) M_{a}\left(\frac{V}{A}\right)$

where $R_{s}$ is the soil respiration $\left(\mu \mathrm{mol} \mathrm{CO} \mathrm{m}^{-2} \mathrm{~s}^{-1}\right), P$ is the air pressure $(\mathrm{kPa})$, $20 T_{\text {soil }}$ is soil temperature at $15 \mathrm{~cm}(\mathrm{~K}), \mathbb{R}$ is the specific gas constant for ideal air $\left(287.053 \mathrm{~J} \mathrm{~kg}^{-1} \mathrm{~K}^{-1}\right), V$ is the chamber volume $\left(\mathrm{m}^{3}\right), A$ is the chamber horizontal area $\left(\mathrm{m}^{2}\right)$ and $M_{a r}$ is the molar weight of dry air $\left(28.9645 \mathrm{~g} \mathrm{~mol}^{-1}\right)$.

\subsection{Soil temperature, soil moisture and litterfall}

The soil temperature at $15 \mathrm{~cm}$ depth was measured using a thermometer (T107, Camp- bell Sci, USA), installed near individual chambers. Soil moisture was measured using

6152
BGD

6, 6147-6177, 2009

Soil respiration and simple models in Amazon forest

F. B. Zanchi et al.

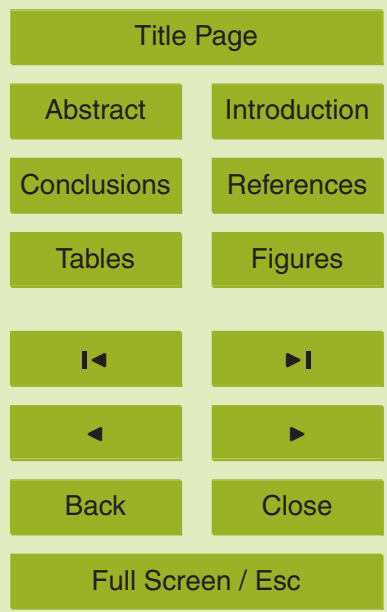

Printer-friendly Version

Interactive Discussion 
Frequency Domain Reflectometry - (CS615, Campbell Sci., USA) with one sensor installed near each chamber, inserted in a vertical direction which provided the mean soil water content (\%) between the surface to $25 \mathrm{~cm}$ depth. The soil calibration was developed using a similar methodology of (Bruno et al., 2006), with samples of oxisol 5 collected in a nearby station (Reserva Jarú). Measurements of litterfall were taken using 15 littertraps $\left(1 \mathrm{~m}^{2}\right)$ collectors over an $150 \mathrm{~m} \times 200 \mathrm{~m}$ area surrounding the set of chambers. The collectors were installed $30 \mathrm{~cm}$ above the soil (Newbould, 1967), to avoid influence of the ground on the leaf decomposition, collected twice a month and the leaves were weigthed and dried in an oven for 3 days at $50^{\circ} \mathrm{C}$.

\subsection{Statistics and data analysis}

The measurements were made from April 2003 to February 2004 for soil moisture and until June 2004 for soil temperature. Data gaps occurred due to mechanical malfunctions, heavy storms and a tree falling down on chamber (C4) in November 2003. The average respiration was calculated from 5 automatic chambers. This was done after applying an ANOVA ( $p<0.05$, confidence level) to all five chambers to check for significant correlation between them. From October to December of 2004 a tree fell over chamber $\mathrm{C} 4$ and the soil respiration showed a substantial increase of more than 3 times the normal emission and the statistical test showed no significant correlation. C4 was therefore not included in the average for this period. To preserve the data anal20 ysis, the soil temperature, moisture and respiration were removed from the data set $3 \mathrm{~h}$ after rain events, because normally the data were disturbed by the $\mathrm{CO}_{2}$ spikes after rain. The $Q_{10}$ model (Lloyd and Taylor, 1994), the Reichstein model (Reichstein et al., 2003) for the relation of soil respiration and soil temperature and the polynomial logarithmic (log-soil) Davidson et al. (2000) fit curve for the soil respiration and soil moisture 25 (models are explained in the results section) were tested by fitting the observations using a nonlinear least square fit and also the Root Mean Square Errors (RMSE) were calculated to explain how well the model fits to the real data. All tests were optimized using Matlab Software (Version 6.5.0.1, The MathWorks, Inc.).

BGD

6, 6147-6177, 2009

Soil respiration and simple models in Amazon forest

F. B. Zanchi et al.

Title Page

Abstract

Introduction

Conclusions

Tables

References

Figures

14

$\rightarrow$

4

Back

Close

Full Screen / Esc

Printer-friendly Version

Interactive Discussion 


\section{Results}

\subsection{Temporal variation}

We discuss how mean half hourly soil respiration varied on the diel cycle, and the patterns of seasonal variability, soil temperature and soil moisture. The mean diel 5 cycle of soil respiration is shown in Fig. 1, for averages calculated in a dry period (28 July 2003 to 1 August 2003) and in a wet period (25-30 December 2003). During the dry period, the soil respiration peaked in the afternoon, around $15 \mathrm{~h}$, at $\sim 7 \mu \mathrm{mol} \mathrm{CO} \mathrm{CO}_{2} \mathrm{~m}^{-2} \mathrm{~s}^{-1}$. In the wet period the mean soil respiration was remarkably higher during the nighttime than in the daytime, and peaked early in the evening, be10 tween 18 and $22 \mathrm{~h}$, at $\sim 10 \mu \mathrm{mol} \mathrm{CO}_{2} \mathrm{~m}^{-2} \mathrm{~s}^{-1}$. The mean daily amplitude of soil respiration was of $\sim 4 \mu \mathrm{mol} \mathrm{CO} \mathrm{Cm}_{2}^{-2} \mathrm{~s}^{-1}$ in the wet period, and nearly half of that in the dry period, of $\sim 2.5 \mu \mathrm{mol} \mathrm{CO} \mathrm{m}^{-2} \mathrm{~s}^{-1}$. As expected, soil temperature was higher in the wet period $\left(\sim 26.5^{\circ} \mathrm{C}\right)$, and lower in the dry period $\left(\sim 24.0^{\circ} \mathrm{C}\right)$, and varied less than $1^{\circ} \mathrm{C}$ day round. The soil temperature peaked between 14 to $21 \mathrm{~h}$ in both the dry and wet periods. Similar soil temperature results were found by Alvalá et al. (2002) and Meir et al. (1996) in tropical amazonian forests. The minimum soil respiration for both periods occurred during the first hours of morning time, between 6 to $9 \mathrm{~h}$, which was concurrent with minimum soil temperature. Some authors report the correlation of soil respiration with soil temperature at 2 or $5 \mathrm{~cm}$ (e.g., Meir et al., 1996). The measured soil temperatures at $15 \mathrm{~cm}$ probably did not cause a substantial lag between half-hourly data of temperature and soil respiration that prejudiced the regression as the diurnal amplitude of soil temperature is often small below the tropical forest canopy (Alvalá et al., 2002), but in different soils as sand soil or more clay as in central Amazonian plateaus, we can find in this dept some hysteresis between both (Zanchi et al., 2009). Davidson et al. (1998) reported the maxima soil respiration and soil temperature around $18 \mathrm{~h}$, in a primary forest of eastern Amazonia, which coincides with the diel cycle pattern in the dry period. On the perspective of the seasonal variability, the lowest mean soil respiration

Soil respiration and simple models in Amazon forest

F. B. Zanchi et al.

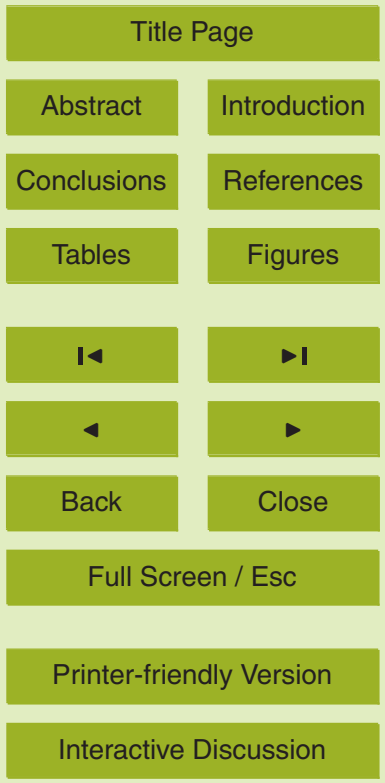

Interactive Discussion 
was noticed in August and within the dry season, of $\sim 1 \mu \mathrm{mol} \mathrm{CO} \mathrm{m}^{-2} \mathrm{~s}^{-1}$, concurrent with the lowest soil temperature and soil moisture $\left(\sim 23^{\circ} \mathrm{C}\right.$ and $0.1 \mathrm{~m}^{3} \mathrm{~m}^{-3}$, respectively) (Fig. 2). The maxima of soil temperature and moisture were $\sim 28^{\circ} \mathrm{C}$ and $0.55 \mathrm{~m}^{3} \mathrm{~m}^{-3}$, respectively, in January and within the rainy season and the soil respiration peaked at $5 \sim 19 \mu \mathrm{mol} \mathrm{CO}_{2} \mathrm{~m}^{-2} \mathrm{~s}^{-1}$ occasionally in the early as well as later on the rainy season. The peak of soil respiration in September (Fig. 3) is marked by the end of a long dry period and the start of several rain events, which was also accompanied by the rapid increase of soil temperature and soil moisture. Litterfall was maximum in the dry season, in August 2003 and May 2004, of about $70 \mathrm{~g} \mathrm{~m}^{-2}$, and remained approximatelly constant during the wet season at approximated rates of $40 \mathrm{~g} \mathrm{~m}^{-2}$. Litterfall is usually maximum during the dry season in the tropical forests (Luizão and Schubart, 1987). In more detail, soil respiration varies abruptly after the first rain events in September (Fig. 4) (see the ellipses in Fig. 4a). In addition, soil moisture also increased abruptly from 0.09 to $0.25 \mathrm{~m}^{3} \mathrm{~m}^{-3}$ (Fig. 4b) during the rain events, associated with the pulses of 15 soil respiration. We argue that air within empty soil pores was replaced by drained water, that drove the $\mathrm{CO}_{2}$ out of the soil, similar to other observations using soil chambers (Matteucci et al., 2000). In addition, the pulses may be associated with other biological controls, as regrowth, the increase of microbial activity which arise from to dead microbial cells accumulated during the drought, and the release of organic solutes from live and dead cells following wetting (Kieft et al., 1987; Howard and Howard, 1993; Davidson et al., 2000, 2005).

\subsection{Modelling the dependence on soil moisture and temperature}

We discuss the dependence of soil respiration $\left(R_{s}\right)$ on soil temperature $\left(T_{\text {soil }}\right)$ at $15 \mathrm{~cm}$ depth firstly based with two simple models: the exponential $Q_{10}$ model (Eqs. 2 and 3), and the Reichstein model (Lloyd and Taylor, 1994). The first model is described as

$R_{s}=R_{0} * e^{\left(\beta_{0} * T_{\text {soil }}\right)}$

$Q_{10}=e^{10 * \beta_{0}}$

BGD

6, 6147-6177, 2009

Soil respiration and simple models in Amazon forest

F. B. Zanchi et al.

Title Page

Abstract

Introduction

Conclusions

Tables

References

Figures

14

$\rightarrow$

4

Back

Close

Full Screen / Esc

Printer-friendly Version

Interactive Discussion 
where $R_{0}$ and $\beta_{0}$ are the fitted parameters, $Q_{10}$ is a sensitivity parameter of the respiration variation with a variation in temperature of $10^{\circ} \mathrm{C}$. This model does not describe soil

BGD moisture and others factors directly, that is, they do not limit respiration explicitly (Lloyd and Taylor, 1994; Fang and Moncrieff, 2001; Janssens and Pilegaard, 2003; Reichstein 5 et al., 2003; Yuste et al., 2004). The second model re-introduces the Arrhenius model (Lloyd and Taylor, 1994) and adds an explicit water dependence to the soil temperature and respiration, which includes the water content relative to the soil water content at field capacity (RSWC), namely as:

$R_{s}=R_{\text {ref }} * f\left(T_{\text {soil }}, \mathrm{RSWC}\right) * g(\mathrm{RSWC})$,

$f\left(T_{\text {soil }}, \mathrm{RSWC}\right)=e^{E_{0}(\mathrm{RSWC})\left(\frac{1}{T_{\text {ref }}-T_{0}}-\frac{1}{T_{\text {soil }}-T_{0}}\right)}$

$g(\mathrm{RSWC})=\frac{\mathrm{RSWC}}{\mathrm{RSWC}_{1 / 2}+\mathrm{RSWC}}$

$E_{0}(\mathrm{RSWC})=a \mathrm{REW}+b \mathrm{REW} * \mathrm{RSWC}$

$\mathrm{RSWC}=\frac{\mathrm{SWC}}{\mathrm{SWC}_{1 / 2}}$

where $R_{\text {ref }}\left(\mu \mathrm{molCO} \mathrm{CO}^{-2} \mathrm{~s}^{-1}\right)$ is the soil respiration at the reference temperature ${ }_{15} T_{\text {ref }}=25^{\circ} \mathrm{C}$ (approximately equal to the local annual mean soil temperatures), $E_{0}\left(\mathrm{~K}^{-1}\right)$ is the activation energy and $T_{0}\left(-46^{\circ} \mathrm{C}\right)$ is the lower temperature limit for the soil respiration from the original model of Lloyd and Taylor (1994), and RSWC1/2 (dimensionless) is the soil water content where half-maximal respiration (at a given temperature) occurs. Reichstein et al. (2003) proposed that the temperature sensitivity of soil respiration is 20 exponentially dependent on the soil water status (Eq. 5), and in a first approximation the exponential power $E_{0}$ is linearly dependent on RSWC for the Eq. (7).

Both models were fitted to the entire data set (Fig. 5a, Table 1). The correlations with the soil temperature and soil moisture were weak, for the $Q_{10}$ model $\left(R^{2}=0.17, Q_{10}=3.9\right.$
$6,6147-6177,2009$

Soil respiration and simple models in Amazon forest

F. B. Zanchi et al.

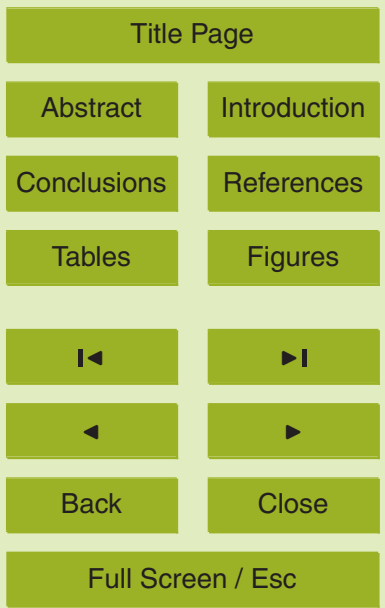

Printer-friendly Version

Interactive Discussion 
and RMSE=3.12) and also for the Reichstein model $\left(R^{2}=0.17\right.$ and RMSE $\left.=3.11\right)$ and were not significant. We noticed that, from 23 to about $26^{\circ} \mathrm{C}$, the soil respiration increased, but tended to decrease above this temperature range because in Amazon region the increase of soil temperature means also soil moisture increase, which makes 5 more difficult to fit the models.

An alternative and third (log-soil) model is presented here (Eq. 9), derivate from the Davidson et al. (2000), which is a nonlinear dependence of the natural logarithm on the soil moisture, as:

$R_{s}=a+b * \ln (\theta)+c * \ln ^{2}(\theta)$

10 where $R_{s}\left(\mu \mathrm{mol} \mathrm{CO} \mathrm{m}^{-2} \mathrm{~s}^{-1}\right)$ is the soil respiration and $\theta\left(\mathrm{m}^{3} \mathrm{~m}^{-3}\right)$ is the volumetric soil moisture content, $a$ can be called the soil activation energy, $b$ is the parameter for the soil respiration close to the water field capacity, and $c$ is the soil respiration decrease when the soil water content is higher than $\theta>0.25 \mathrm{~m}^{3} \mathrm{~m}^{-3}$ or lower than $\theta<0.15 \mathrm{~m}^{3} \mathrm{~m}^{-3}$.

The model was fitted with the soil moisture data (Fig. $5 \mathrm{~b}$, Table 1) $\left(R^{2}=0.31\right.$;

$15 \mathrm{RMSE}=2.81 ; p<0.05)$, and despite the weak correlation, suggested that soil respiration responded to soil moisture variation around an optimum soil moisture that maximizes respiration, that is, respiration decreased for soil water content low and high (i.e., below and above field capacity). Such optimum soil water content was noticed, by simple inspection, to be between 0.2 and $0.3 \mathrm{~m}^{3} \mathrm{~m}^{-3}$, which is close to the field capacity of oxisols.

To help understanding the dependence of soil respiration to soil temperature and soil moisture, the model fitting was separated for 3 different classes of soil moisture (Fig. 6). The $Q_{10}$ soil respiration model and the Reichstein model were fitted with data specifically for the period of data constrained by the following classes of soil mois25 ture: (a) $0.09<\theta<0.115 \mathrm{~m}^{3} \mathrm{~m}^{-3}$; (b) $0.115<\theta<0.25 \mathrm{~m}^{3} \mathrm{~m}^{-3}$ and (c) $\theta>0.3 \mathrm{~m}^{3} \mathrm{~m}^{-3}$. In the drier range (Fig. 6a, Table 1), soil respiration shows a clear exponential pattern for both models. In this range, coincident with the dry season, soil temperature was low and also limited respiration. The regression coefficients were however low $\left(Q_{10}\right.$ model

\section{BGD}

6, 6147-6177, 2009

Soil respiration and simple models in Amazon forest

F. B. Zanchi et al.

Title Page

Abstract

Introduction

Conclusions

Tables

References

Figures

14

$\rightarrow 1$

4

Back

Close

Full Screen / Esc

Printer-friendly Version

Interactive Discussion 
showed $R^{2}=0.26$ with $\mathrm{RMSE}=1.30$ and the Reichstein models showed $R^{2}=0.27$, and RMSE $=1.28$ ). The estimate of the parameter $Q_{10}$ was equal to 12 , which is relatively high when compared to other estimates for tropical forest (Meir et al., 1996; Sotta et al., 2004). In this case, the amplitude of temperature was quite small (of about $2^{\circ} \mathrm{C}$ ), which 5 makes the calculated $Q_{10}$ parameter to increase. For the second class of data, the intermediate soil moisture range (Fig. 6b, Table 1), the models also appeared as an exponential fitting, although the range of temperature was larger than that of the first class, of about $3.5^{\circ} \mathrm{C}$. In this case, the regression coefficients were also low, although the Reichstein model fitted a little better than the simple $Q_{10}$ exponential model (Reichstein: $R^{2}=0.33 ; \mathrm{RMSE}=2.76$ and $Q_{10}: R^{2}=0.25$ and $\mathrm{RMSE}=2.91$ ). The calculated $Q_{10}$ parameter was equal to 8.8 . For the third class, that is, for the data within the period on the upper ranges of soil moisture, in the wet season, no correlation was significantly estimated $\left(R^{2}<0.04\right)$ (Fig. 6c). In this case, soil respiration was not sensitive to the temperature variation for the very wet soil conditions, according to those models.

15 Furthermore, we fitted the model dependent on log-soil moisture (Eq. 9) constrained by the same range of soil moisture: in the first class (Fig. 7a), soil respiration appeared to be strongly reduced near the lowest limit of soil moisture. In addition, soil respiration remains low and approximately constant (no sensitivity to the low humidity) for $\theta \leq 0.106 \mathrm{~m}^{3} \mathrm{~m}^{-3}$ and starts to increase for moisture above $0.106 \mathrm{~m}^{3} \mathrm{~m}^{-3}$, un20 der a modest regression $\left(R^{2}=0.36\right)$. In Fig. $7 \mathrm{~b}$, the middle soil moisture class, soil respiration is reduced in both the lower and upper thresholds of the classes, and varies non-linearly around an maximum in the range of soil moisture of approximately $\left(0.15<\theta \leq 0.25 \mathrm{~m}^{3} \mathrm{~m}^{-3}\right)$. Finally, for the third class (Fig. 7c) of data, no clear fitting was suggested. In this interval there was a large variation of soil respiration, between $\sim 0.4$ 25 to $14 \mu \mathrm{mol} \mathrm{CO} \mathrm{m}^{-2} \mathrm{~s}^{-1}$, and other controls may be likely more important rather than the moisture.

We calculated the fittings of the three models, using the mean monthly data instead of half-hourly for the entire set of data to be possible to understand better the Lagtime of the soil respiration to soil temperature and moisture. The regression explained

BGD

$6,6147-6177,2009$

Soil respiration and simple models in Amazon forest

F. B. Zanchi et al.

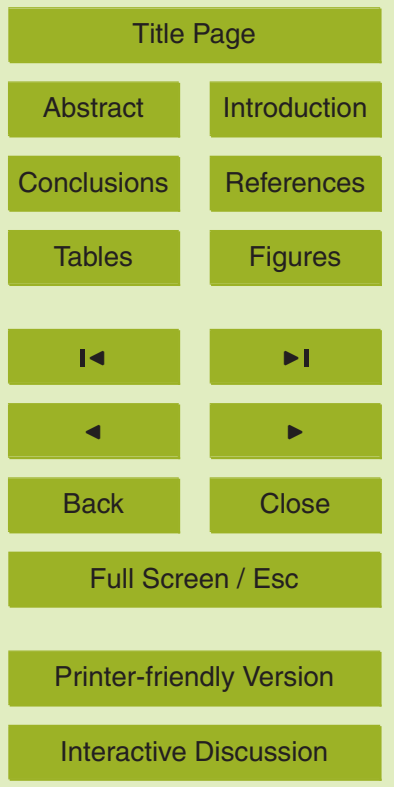

Interactive Discussion 
over $65 \%$ of the variance for the Exponential model, with a calculated $Q_{10}$ parameter equal to 3.9 and $46 \%$ for the Reichstein model (Fig. 8a), and over $49 \%$ for the log-soil moisture model (Fig. 8b). Furthermore, we fitted the models to the data averaged on a variable scale of periods, between 1 day and 30 days. The results showed that the

$5 R^{2}$ coefficient, for all models, appeared to depend on the period of averaging, with the fitting (based on $R^{2}$ and RMSE) improving progressively with the days Lag-time period (Table 2).

\section{Discussion}

The measurements of soil respiration in a tropical forest in southwestern Amazonia 10 varied seasonally, lower in the dry season and higher in the wet season, and generally responded positively to the variation of soil moisture and temperature year round. The peak of the soil respiration happened remarkably in the dry-to-wet season transition (September). We estimated an average emission equal to $\left(8 \pm 3.4 \mu \mathrm{mol} \mathrm{CO}_{2} \mathrm{~m}^{-2} \mathrm{~s}^{-1}\right)$ over an approximated period of 10 months which comprised the dry and the wet sea15 son. The mean half hourly data showed a large annual amplitude, which varied from $\sim 0.62$ to $18.9 \mu \mathrm{mol} \mathrm{CO} \mathrm{m}^{-2} \mathrm{~s}^{-1}$. Davidson (1993) and Chambers et al. (2004) showed increases in soil moisture content to lead to decreases in soil respiration, which must have been likely caused by inhibition of respiratory activity due to inadequate oxygen supply in saturated soils (Linn and Doran, 1984). Chambers et al. (2004) associated this pattern with the topography of Amazonian terra firme forests, and attributed the wetter soils under the valleys as the pre-condition which sustains such mechanism. Our measurements do not meet exactly those reports, also because the study site was more similar to the plateau forest types. Soil respiration reached the highest emission in the dry-to-wet season (transition) and was associated with the increase of soil temperature and soil moisture. Such a variability coincided with increasing sunlight and evapotranspiration year round in a nearby station, a primary forest at Reserva Jarú in Rondônia (da Rocha et al., 2009), and are also correlated with the increasing ecosystem productivity at that same station (Saleska et al., 2009). Increasing productivity and

BGD

$6,6147-6177,2009$

Soil respiration and simple models in Amazon forest

F. B. Zanchi et al.

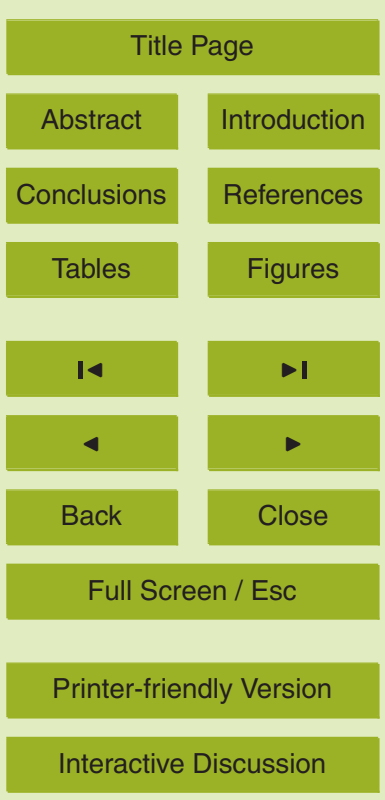

Interactive Discussion 
transpiration in turn may affect positively root respiration, especially the fine roots in the shallower soil layers, and partly explains the increasing soil respiration. It is remarkable how such fast dry-to-wet season transition in southwest Amazon was captured with the measurements, and appeared to show the most significant variation in intra-seasonal 5 soil respiration. Furthermore, heterotrophic controls play a strong role in the peak of soil respiration, especially the highest litterfall rates during the middle dry season. At that time, soil microorganisms have certainly met very favorable conditions for biomass decomposition, especially the fresh litter on the forest floor accumulated during the dry season, and the increasing temperature and moisture. The direct reaction of soil respi10 ration to soil moisture could be partly explained by the heterotrophic component, when the decomposition is activated with the increase of the microorganisms and mycorrhizae, after a long dry spell, that correspond to $25 \%$ of primary productivity (Lankreijer et al., 2002). Our observations corroborate more closely the increase of soil respiration over an eastern Amazonian forest in Santarém (Goulden et al., 2004) in late December, 15 or more exactly the onset of the wet season regionally. Particularly, our measurements were relatively higher during the wet season compared to then, it appeared to be more transient than that authors. We argue that processes as carbon decomposition and turn-over may be possibly faster in our study site than in Santarém during the wet season. The increase of soil respiration in the early wet season agrees with other observations in eastern Amazonia (Davidson et al., 2000; Sotta et al., 2004) and in a southwestern tropical forest in Acre (Salimon et al., 2004). Our analysis of modelling the half-hourly soil respiration suggests that the $Q_{10}$ and the Reichstein models will hardly explain the variance of the observations significantly, partly because the data scattering is high. However, it is suggested that the models tend to represent the mean statistics, and do not contradict the observations entirely. The performance of the regression improves when the mean variables are calculated over longer periods, up to one month, which make the model fit more smooth the intra-seasonal variation. The $Q_{10}$ coefficient was possibly overestimated (see Table 1 ), and may lead to erroneous calculation at warmer temperatures, which is partly explained by the narrow amplitude

BGD

6, 6147-6177, 2009

Soil respiration and simple models in Amazon forest

F. B. Zanchi et al.

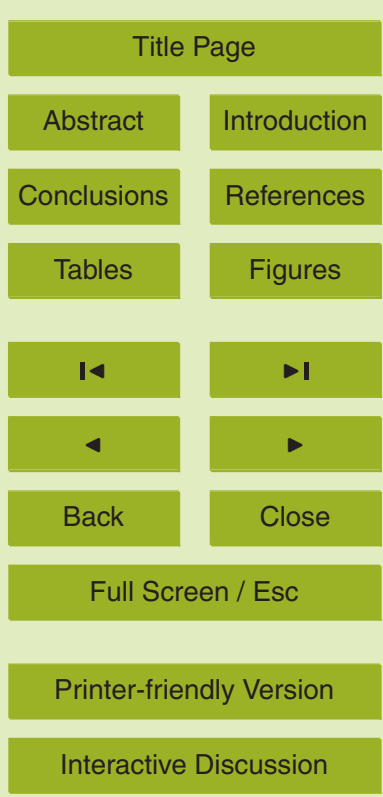

Interactive Discussion 
of soil temperature observed in the tropical forests, of $\sim 5^{\circ} \mathrm{C}$, in comparison to high annual amplitudes in temperature zones, usually $>20^{\circ} \mathrm{C}$ (Janssens and Pilegaard, 2003). This is to be noticed in the use of global climate models which deploy simple parameterizations dependent only on temperature, and especially the exponential coefficient $5 Q_{10}$ (Parton et al., 1987; Hunt Jr. et al., 1996; Cox et al., 2000), as it seems difficult to predict the soil respiration when strong climate anomalies dominate the tropics. Moreover, the dependence of soil moisture did not contribute to increase the explained variance in the Reichstein model, as its representation may not be satisfactorily especially when the soil moisture and litterfall vary substantially. We did not find an optimal 10 temperature at which biological processes are maximum (other environmental factors constant) (Fang and Moncrieff, 2001). However the observations clearly suggested an optimum soil moisture range. Linn and Doran (1984) and Davidson (1993) have suggested that an interval between 0.2 to $0.7 \mathrm{~m}^{3} \mathrm{~m}^{-3}$ is likely optimum. We found it between 0.115 to $0.25 \mathrm{~m}^{3} \mathrm{~m}^{-3}$, which obviously depend much on the soil porosity, and 15 not entirely on the absolute soil water content.

\section{Conclusions}

We concluded that, for the benefit of the modelling, the data could be stratified, or separated by different classes of soil moisture. The $Q_{10}$ and the Reichstein model showed the worst performance when soil water content was high, as the dependence of temperature in the observation was not obvious. In general, the data stratification helped slightly the $Q_{10}$ and Reichstein model to improve the fitting. To achieve an explicit representation of the soil moisture, we deployed the log-soil moisture model, which in turn showed to be helpful to describe the optimum soil moisture range. In comparison to the other models, however, it did not improve substantially the explained variance of the observations. The scattering of the half-hourly data also prejudiced the model regression. Especially in the very wet soil conditions, all models generally fail in correlating either temperature or moisture. Overall the modelling of soil respiration over our tropical forest study area showed the dependence of single variables as soil

\section{BGD}

$6,6147-6177,2009$

Soil respiration and simple models in Amazon forest

F. B. Zanchi et al.

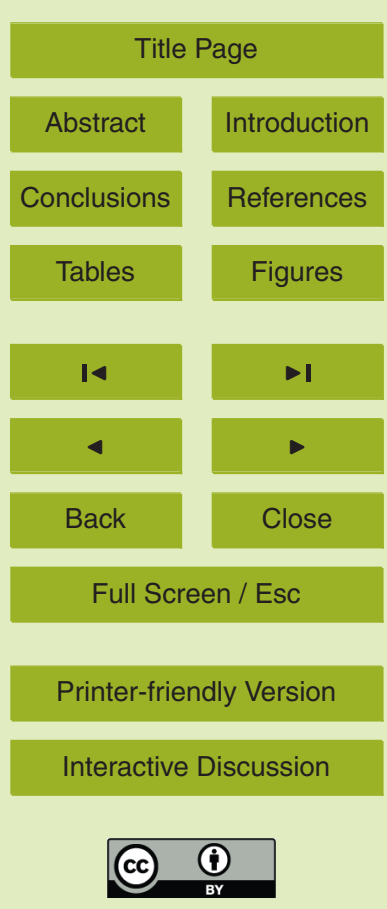


temperature and moisture can be helpful although certainly limited. To improve the modelling of the seasonal variability, other variables should be required, as for example soil structure, and more importantly, gross productivity and litterfall, which correlate with temperature and moisture in the tropics, but also depend on circadian rhythms and are 5 species-dependent.

Acknowledgements. Special thanks for Walter Meira, owner of Itapirema's ranch (Walter Meira) and the Engineer Nilson L. Neres from IAG/USP for his work to build up the electronic parts of the $\mathrm{CO}_{2}$ Chambers set. The authors also acknowledge that without the maintenance and logistic of UNIR in Ji-Paraná the project will be not possible. The research was supported by LBA/UNIR, Ji-Paraná, Large-scale Biosphere-Atmosphere (LBA) project, Brazilian agencies Conselho Nacional de Pesquisa e Desenvolvimento Tecnológico (CNPq) and Fabrício B. Zanchi scholarship research project was supported by the CAPES (Brazil) and fieldwork was also sponsored by the Dutch Ministry for Agriculture, Food and Fisheries.

\section{References}

Alvalá, R. C. S., Gielow, R., da Rocha, H. R., Freitas, H. C., Lopes, J. M., Manzi, A. O., von Randow, C., Dias, M. A. F. S., Cabral, O. M. R., and Waterloo, M. J.: Intradiurnal and seasonal variability of soil temperature, heat flux, soil moisture content, and thermal properties under forest and pasture in Rondônia, J. Geophys. Res., 107(D20), 8043, doi:10.1029/2001JD000599, 2002. 6154

20 Ballester, M., de C. Victoria, D., Krusche, A., Coburn, R., Victoria, R., Richey, J., Logsdon, M., Mayorga, E., and Matricardi, E.: A remote sensing/GIS-based physical template to understand the biogeochemistry of the Ji-Paraná river basin (Western Amazônia), Remote Sens. Environ., 87, 429-445, available at: http://lba.cptec.inpe.br/lba/eng/docs/publications/ science/Ballester.pdf, 2003. 6151

Betts, R. A., Cox, P. M., Collins, M., Huntingford, P. P. H. C., and Jones, C. D.: The role of ecosystem-atmosphere interactions in simulated Amazonian precipitation decrease and forest dieback under global climate warming, Theor. Appl. Climatol., 78, 157-175, 2004. 6149

Bruno, R. D., da Rocha, H. R., de Freitas, H. C., Goulden, M. L., and Miller, S. D.: Soil moisture

BGD

$6,6147-6177,2009$

Soil respiration and simple models in Amazon forest

F. B. Zanchi et al.

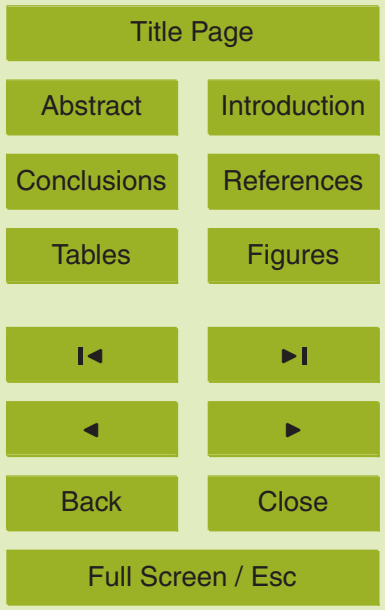

Printer-friendly Version

Interactive Discussion 
dynamics in an eastern Amazonian tropical forest, Hydrol. Process., 20, 2477-2489, 2006. 6153

Buchmann, N., Guehl, J., Barigah, T. S., and Ehleringer, J. R.: Interseasonal comparison of $\mathrm{CO}_{2}$ concentrations, isotopic composition, and carbon dynamics in an Amazonian rainforest

5 (French Guiana), Oecologia, 110, 120-131, 1997. 6149

Chambers, J. Q., Tribuzy, E. S., Toledo, L. C., Crispim, B. F., Higuchi, N., dos Santos, J., de Araújo, A. C., Kruijt, B., Nobre, A. D., and Trumbore, S.: Respiration from a tropical forest ecosystem: partitioning of sources and low carbon use efficiency, Ecol. Appl., 14, S72-S88, available at: http://www.esajournals.org/doi/pdf/10.1890/01-6012, supplement, 2004. 6151, $10 \quad 6159$

Cox, P. M., Betts, R. A., Jones, C. D., Spall, S. A., and Totterdell, I. J.: Acceleration of global warming due to carbon-cycle feedbacks in a coupled climate model, Nature, 408, 184-187, 2000. 6161

Culf, A., Esteves, J., Marques Filho, A., and da Rocha, H.: Radiation, temperature and humidity 15 over forest and pasture in Amazonia, in: Amazonian Deforestation and Climate, edited by: Gash, J., Nobre, C., Roberts, J., and Victoria, R., John Wiley, 175192, 1996. 6151

da Rocha, H., Goulden, M., Miller, S., Menton, M., Pinto, L., de Freitas, H., and Figueira, A.: Seasonality of water and heat fluxes over a tropical forest in eastern Amazonia, Ecol. Appl., 14, S22-S32, available at: http://www.ess.uci.edu/ goulden/da\%20Rocha\%20et\%

$20 \quad$ 20al\%2004.pdf, supplement, 2004. 6150

da Rocha, H. R., Manzi, A. O., Cabral, O. M., Miller, S. D., Goulden, M. L., Saleska, S. R., Coupe, N. R., Wofsy, S. C., Borma, L. S., Artaxo, P., Vourlitis, G., Nogueira, J. S., Cardoso, F. L., Nobre, A. D., Kruijt, B., Freitas, H. C., von Randow, C., Aguiar, R. G., and Maia, J. F.: Patterns of water and heat flux across a biome gradient from tropical forest to savanna in

25 Brazil, J. Geophys. Res., 114, G00B12, doi:10.1029/2007JG000640, 2009. 6151, 6159

Davidson, E. A.: Soil water content and the ratio of nitrous oxide to nitric oxide emitted from soil, in: Biogeochemistry of Global Change: Radiatively Active Trace Gases, edited by: Oremland, R. S., Chapman and Hall, New York, New York, USA, 369-386, 1993. 6150, 6159, 6161

30 Davidson, E. A., Belk, E., and Boone, R. D.: Soil water content and temperature as independent or confounded factors controlling soil respiration in a temperate mixed hardwood forest, Glob. Change Biol., 4, 217-227, available at: http://dx.doi.org/10.1046/j.1365-2486.1998.00128.x, 1998. 6149,6154

BGD

6, 6147-6177, 2009

\section{Soil respiration and simple models in Amazon forest}

F. B. Zanchi et al.

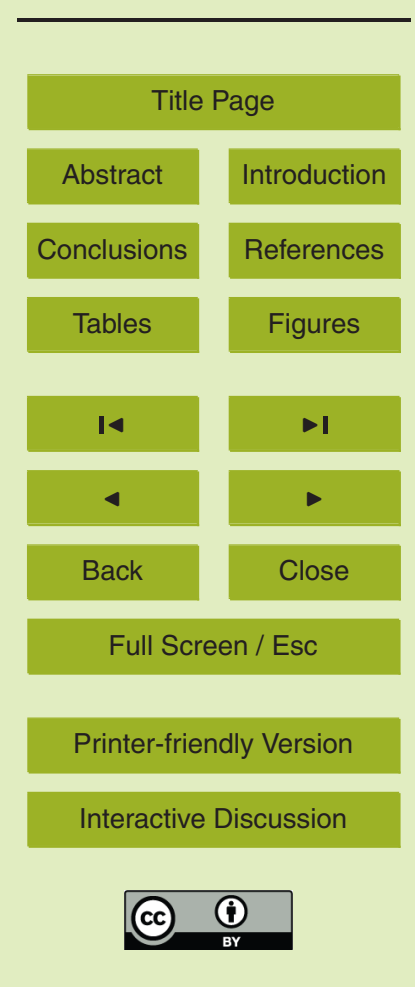


Davidson, E. A., Verchot, L. V., Cattnio, J. H., Ackerman, I. L., and Carvalho, J.: Effects of soil water content on soil respiration in forests and cattle pastures of eastern Amazonia, Biogeochemistry, 48, 53-69, available at: http://www.springerlink.com/content//83p811676736534, 2000. 6149, 6153, 6155, 6157, 6160

5 Davidson, E. A., Janssens, I. A., and Luo, Y.: On the variability of respiration in terrestrial ecosystems: moving beyond $Q_{10}$, Glob. Change Biol., 12, 154-164, 2005. 6155

Davidson, E. A., Nepstad, D. C., Ishida, F. Y., and Brando, P. M.: Effects of an experimental drought and recovery on soil emissions of carbon dioxide, methane, nitrous oxide, and nitric oxide in a moist tropical forest, Glob. Change Biol., 14, 2582-2590, 2008. 6150

10 de Araújo, A., Nobre, A. D., Kruijt, B., Elbers, J. A., Dallarosa, R., Stefani, P., von Randow, C., Manzi, A. O., Culf, A. D., Gash, J. H. C., Valentini, R., and Kabat, P. P.: Comparative measurements of carbon dioxide fluxes from two nearby towers in a central Amazonian rainforest: The Manaus LBA site, J. Geophys. Res., 107(D20), 8090, doi:10.1029/2001JD000676, 2002. 6149

15 Fang, C. and Moncrieff, J. B.: The dependence of soil $\mathrm{CO}_{2}$ efflux on temperature, Soil Biol. Biochem., 33, 155-165, available at: http://www.sciencedirect.com/science? $\_o b=$ ArticleURL\&_udi=B6TC7-41YG2YJ-3\&_user=499882\&_rdoc=1\&_fmt=\&_orig = search\&_sort=d\&view $=$ c\&_acct $=$ C000024498\&_version=1\&_urlVersion=0\&_userid = 499882\&md5=cf989fc27df7f8eb3ad89d389a8a94ae, 2001. 6156, 6161

20 Giardina, C. P. and Ryan, M. G.: Evidence that decomposition rates of organic carbon in mineral soil do not vary with temperature, Nature, 404, 858-861, available at: http://www.nature.com/ nature/journal/v404/n6780/full/404858a0.html, 2000. 6150

Goulden, M. L., Miller, S. D., da Rocha, H. R., Menton, M. C., de Freitas, H. C., Figueira, A. M. S., and de Sousa, C. A. D.: Diel and seasonal patterns of tropical forest $\mathrm{CO}_{2}$ exchange, Ecol. Appl., 14, 42-54, 2004. 6149, 6150, 6160

Howard, D. and Howard, P.: Relationships between $\mathrm{CO}_{2}$ evolution, moisture content and temperature for a range of soil types, Soil Biol. Biochem., 25, 1537-1546, 1993. 6149, 6150, 6155

Irvine, J. and Law, B. E.: Contrasting soil respiration in young and old-growth ponderosa pine forests, Glob. Change Biol., 8, 1183-1194, available at: http://dx.doi.org/10.1046/j. 1365-2486.2002.00544.x, 2002. 6150

Janssens, I. A. and Pilegaard, K.: Large seasonal changes in $Q_{10}$ of soil respiration in a beech forest, Glob. Change Biol., 9, 911-918, available at: http://dx.doi.org/10.1046/j.1365-2486.

Soil respiration and simple models in Amazon forest

F. B. Zanchi et al.

Title Page

Abstract

Introduction

Conclusions

References

Tables

Figures

14

$\rightarrow$

4

Back

Close

Full Screen / Esc

Printer-friendly Version

Interactive Discussion 
2003.00636.x, 2003. 6150, 6156, 6161

Janssens, I. A., Lankreijer, H., Matteucci, G., Kowalski, A. S., Buchmann, N., Epron, D., Pilegaard, K., Kutsch, W., Longdoz, B., Grünwald, T., Montagnani, L., Dore, S., Rebmann, C., Moors, E. J., Grelle, A., Rannik, K., Morgenstern, K., Oltchev, S., Clement, R., Gudmundsson, J., Minerbi, S., Berbigier, P., Ibrom, A., Moncrieff, J., Aubinet, M., Bernhofer, C., Jensen, N. O., Vesala, T., Granier, A., Schulze, E. D., Lindroth, A., Dolman, A. J., Jarvis, P. G., Ceulemans, R., and Valentini, R.: Productivity overshadows temperature in determining soil and ecosystem respiration across European forests, Glob. Change Biol., 7, 269-278, available at: http://dx.doi.org/10.1046/j.1365-2486.2001.00412.x, 2001. 6149

10 Janssens, I. A., Dore, S., Epron, D., Lankreijer, H., Buchmann, N., Longdoz, B., Brossaud, J., and Montagnani, L.: Climatic influences on seasonal and spatial differences in soil $\mathrm{CO}_{2}$ Efflux, in: Canopy Fluxes of Energy, Water and Carbon Dioxide of European Forests, edited by: Valentini, R., Springer-Verlag, Berlin, Germany, 235-256, 2003. 6149, 6150

Hunt Jr., E. R., Piper, S. C., Nemani, R., Keeling, C. D., Otto, R. D., and Running, S. W.: 15 Global Net Carbon Exchange and Intra-annual Atmospheric $\mathrm{CO}_{2}$ Concentrations Predicted by an Ecosystem Process Model and Three-Dimensional Atmospheric Transport Model, Global Biogeochem. Cy., 10, 431-456, available at: http://www.agu.org/journals/gb/v010/ i003/96GB01691/, 1996. 6161

Keller, M., Alencar, A., Asner, G. P., Braswell, B., Bustamante, M., Davidson, E., Feldpausch, T., Fernandes, E., Goulden, M., Kabat, P., Kruijt, B., ao, F. L., Miller, S., Markewitz, D., Nobre, A. D., Nobre, C. A., Priante, N., da Rocha, H. R., Dias, P. S., von Randow, C., and Vourlitis, G. L.: Ecological research in the Large-scale Biosphere-Atmosphere experiment in Amazonia: Early results, Ecol. Appl., 14, S3-S16, suppl. S, 2004. 6150

Kieft, T. L., Soroker, E., and Firestone, M. K.: Microbial biomass response to a rapid increase 25 in water potential when dry soil is wetted, Soil Biol. Biochem. 19, 119-126, 1987. 6155

Lankreijer, H., Janssens, I., Buchmann, N., Longdoz, B., Epron, D., and S. Dore, E.: Measurement of Soil Respiration. Fluxes of Carbon, Water and Energy of European Forests, Ecological studies, Springer-Verlag Berlin Heidelberg New York, 164, chap. 3, 2002. 6160

Linn, D. M. and Doran, J. W.: Effect of water filled pore space on $\mathrm{CO}_{2}$ and NO production in tilled and nontilled soils., Soil Sci. Soc. Am. J., 48, 1267-1272, available at: http://ddr.nal. usda.gov/bitstream/10113/16745/1/GUA85010259.pdf, 1984. 6150, 6159, 6161

Liski, J. and Westma, J.: Carbon storage in forest soil of Finland. 1. Effect of thermoclimate, Biogeochemistry, 36, 239-260, available at: http://www.springerlink.com/content/

BGD

6, 6147-6177, 2009

\section{Soil respiration and simple models in Amazon forest}

F. B. Zanchi et al.

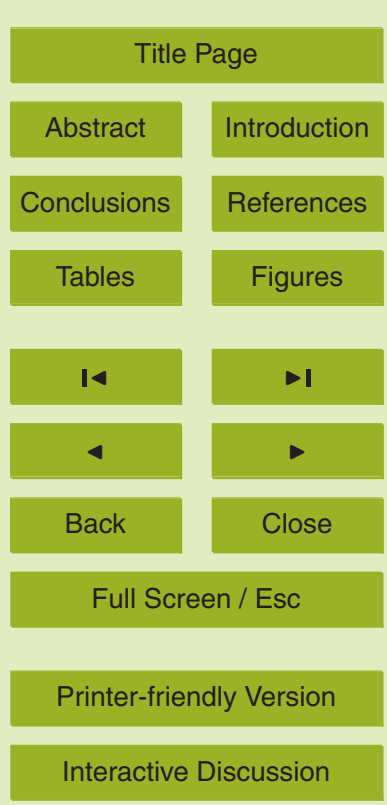


u8u2086t47u8t1x5, 1997. 6150

Lloyd, J. and Taylor, J. A.: On the Temperature Dependence of Soil Respiration, Funct. Ecol., 8, 315-323, available at: http://www.jstor.org/stable/2389824, 1994. 6149, 6150, 6153, 6155, 6156

5 Luizão, F. J. and Schubart, H. O. R.: Litter production and decomposition in a terra-firme forest of Central Amazonia, Experientia, 43, 259-265, 1987. 6155

Matteucci, G., Dore, S., Stivanello, S., Rebmann, C., and Buchmann, N.: Soil Respiration in Beech and Spruce Forests in Europe: Trends, Controlling Factors, Annual Budgets and Implications for the Ecosystem Carbon Balance, Ecological Studies, 142, 217-236, 2000.

\section{$10 \quad 6155$}

Meir, P., Grace, J., Miranda, A., and Lloyd, J.: Soil respiration in a rainforest in Amazonia and in Cerrado in Central Brazil, in: Amazonian Deforestation and Climate, edited by: Gash, J. H. C., Nobre, C. A., Roberts, J. M., and Victoria, R. L., John Wiley and Sons, Chichester, UK, 319-329, 1996. 6149, 6154, 6158

15 Newbould, P. J.: Methods for estimating the primary production of forests, International Biological Programme, Blackwell Scientific Publications, available at: http://coweeta.ecology.uga. edu/webdocs/1/ppforests.html, 1967. 6153

Parton, W. J., Schimel, D. S., Cole, C. V., and Ojima, D. S.: Analysis of Factors Controlling Soil Organic Matter Levels in Great Plains Grasslands, Soil Sci. Soc. Am. J., 51, 1173-1179, http://soil.scijournals.org/cgi/reprint/51/5/1173, 1987. 6161

Raich, J. W., Potter, C. S., and Bhagawati, D.: Interannual variability in global soil respiration, 198094, Glob. Change Biol., 8, 800-812, available at: http://www3.interscience.wiley.com/ journal/118961405/abstract, 2002. 6150

Reichstein, M., Rey, A., Freibauer, A., Tenhunen, J., Valentini, R., Banza, J., Casals, P., Cheng, 25 Y., Grunzweig, J. M., Irvine, J., Joffre, R., Law, B. E., Loustau, D., Miglietta, F., Oechel, W., Ourcival, J.-M., Pereira, J. S., Peressotti, A., Ponti, F., Qi, Y., Rambal, S., Rayment, M., Romanya, J., Rossi, F., Tedeschi, V., Tirone, G., Xu, M., and Yakir, D.: Modeling temporal and large-scale spatial variability of soil respiration from soil water availability, temperature and vegetation productivity indices, Global Biogeochem. Cy., 17, 15.1-15.15, available at: http://www.agu.org/journals/gb/gb0304/2003GB002035/, 2003. 6150, 6153, 6156

Richey, J. E., Melack, J. M., Aufdenkampe, A. K., Ballester, V. M., and Hess, L.: Outgassing from Amazonian rivers and wetlands as a large tropical source of atmospheric $\mathrm{CO}_{2}$, Nature, 416, 617-620, 2002. 6149
BGD

$6,6147-6177,2009$

Soil respiration and simple models in Amazon forest

F. B. Zanchi et al.

Title Page

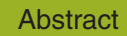

Introduction

Conclusions

Tables

References

Figures

14

- I

4

Back

Close

Full Screen / Esc

Printer-friendly Version

Interactive Discussion 
Saleska, S., da Rocha, H. R., Kruijt, B., and Nobre, A.: Ecosystem carbon fluxes and Amazon forest metabolism, in: Amazonia and Global Change, edited by: Keller, M., Bustamante, M., Gash, J., and Dias, P. S., American Geophysical Union, in press, 2009. 6149, 6150, 6159

Saleska, S. R., Miller, S. D., Matross, D. M., Goulden, M. L., Wofsy, S. C., da Rocha, H. R., 5 de Camargo, P. B., Crill, P., Daube, B. C., de Freitas, H. C., Hutyra, L., Keller, M., Kirchhoff, V., Menton, M., Munger, J. W., Pyle, E. H., Rice, A. H., and Silva, H.: Carbon in amazon forests: Unexpected seasonal fluxes and disturbance-induced losses, Science, 302, 15541557, 2003. 6149, 6150

Salimon, C. I., Davidson, E. A., Victoria, R. L., and Melo, A. W. F.: $\mathrm{CO}_{2}$ flux from soil in pastures and forests in southwestern Amazonia, Glob. Change Biol., 10(5), 833-843, available at: http://www3.interscience.wiley.com/cgi-bin/fulltext/118805468/PDFSTART, 2004. 6149, 6150,6160

Skopp, J., Jawson, M. D., and Doran, J. W.: Steady-State Aerobic Microbial Activity as a Function of Soil Water Content, Soil Sci. Soc. Am. J., 54, 1619-1625, available at: http://hdl.handle.net/10113/1720, 1990. 6150

Sotta, E. D., Meir, P., Malhi, Y., Nobre, A. D., Hodnett, M. G., and Grace, J.: Soil $\mathrm{CO}_{2}$ efflux in a tropical forest in the Central Amazon, Global Change Biol., 10, 601-617, 2004. 6149, 6150, 6158,6160

Valentini, C. M. A., Sanches, L., de Paula, S. R., Vourlitis, G. L., de S. Nogueira, J., Pinto Jr., O. B., and de A. Lobo, F.: Soil respiration and aboveground litter dynamics of a tropical transitional forest in northwest Mato Grosso, Brazil, J. Geophys. Res., 113, G00B10, doi:10.1029/2007JG000619, available at: http://www.agu.org/journals/jg/jg0804/ 2007JG000619/2007JG000619.pdf, 2008. 6150

von Randow, C., Manzi, A. O., Kruijt, B., de Oliveira, P. J., Zanchi, F. B., Silva, R. L., Hodnett, M. G., Gash, J. H. C., Elbers, J. A., Waterloo, M. J., Cardoso, F. L., and Kabat, P.: Comparative measurements and seasonal variations in energy and carbon exchange over forest and pasture in South West Amazonia, Theor. Appl. Climatol., 78, 5-26, 2004. 6149, 6151

Yuste, J. C., Janssens, I. A., Carrara, A., and Ceulemans, R.: Annual $Q_{10}$ of soil respiration reflects plant phenological patterns as well as temperature sensitivity, Glob. Change Biol., 30 10, 161-169, available at: http://dx.doi.org/10.1111/j.1529-8817.2003.00727.x, 2004. 6156 Zanchi, F. B., Kruijt, B., Waterloo, M. J., Kesselmeier, J., Manzi, A. O., and Dolman, J.: Soil respiration from different ecosystem in the central of Amazon forest, in preparation, 2009 6154

BGD

$6,6147-6177,2009$

Soil respiration and simple models in Amazon forest

F. B. Zanchi et al.

Title Page

Abstract

Introduction

Conclusions

Tables

References

Figures

14

$\rightarrow 1$

4

Back

Close

Full Screen / Esc

Printer-friendly Version

Interactive Discussion 
Table 1. Regression parameters and statistics of the models.

6, 6147-6177, 2009

\section{Soil respiration and} simple models in

\begin{tabular}{|c|c|c|c|c|c|c|c|}
\hline \multicolumn{8}{|l|}{ Models } \\
\hline \multirow[t]{2}{*}{ Log model } & \multicolumn{3}{|c|}{ Parameters } & \multicolumn{4}{|c|}{ Statistics } \\
\hline & $a_{0}$ & $b_{0}$ & $c_{0}$ & Rs mean \pm std & model mean \pm Std & $R^{2}$ & RMSE \\
\hline $\begin{array}{l}\text { Dry class } \\
\text { Intermediate }\end{array}$ & $\begin{array}{r}2213 \\
-44.70\end{array}$ & $\begin{array}{r}1934 \\
-65.30\end{array}$ & $\begin{array}{l}423.80 \\
-19.00\end{array}$ & $\begin{array}{l}5.94 \pm 1.44 \\
9.19 \pm 3.41\end{array}$ & $\begin{array}{l}6.18 \pm 1.52 \\
8.03 \pm 3.86\end{array}$ & $\begin{array}{l}0.36 \\
0.28\end{array}$ & $\begin{array}{l}1.20 \\
2.89\end{array}$ \\
\hline Wet class & 18.00 & 19.80 & 12.00 & $10.25 \pm 3.70$ & $9.14 \pm 0.49$ & 0.01 & 3.65 \\
\hline Whole period & -12.50 & -30.30 & -9.60 & $8.43 \pm 3.40$ & $9.28 \pm 1.75$ & 0.31 & 2.81 \\
\hline \multirow[t]{2}{*}{ Exponential model } & \multicolumn{3}{|c|}{ Parameters } & \multicolumn{4}{|c|}{ Statistics } \\
\hline & $R_{0}$ & $b_{0}$ & $Q_{10}$ & Rs mean \pm std & Model mean \pm Std & $R^{2}$ & RMSE \\
\hline Dry class & 0.02 & 0.25 & 12.00 & $6.10 \pm 1.46$ & $5.96 \pm 0.75$ & 0.26 & 1.30 \\
\hline Intermediate & 0.04 & 0.22 & 8.80 & $8.56 \pm 3.35$ & .61 & 0.25 & 2.91 \\
\hline Wet class & 0.18 & 0.15 & 4.30 & $8.92 \pm 3.59$ & $8.69 \pm 0.68$ & 0.03 & 3.50 \\
\hline Whole period & 0.28 & 0.14 & 3.90 & $8.43 \pm 3.40$ & $8.11 \pm 1.32$ & 0.17 & 3.11 \\
\hline \multirow[t]{2}{*}{ Reichstein model } & \multicolumn{3}{|c|}{ Parameters } & \multicolumn{4}{|c|}{ Statistics } \\
\hline & $R_{\text {ref }}$ & RSWC & $E_{0}$ & Rs mean \pm std & Model mean \pm Std & $R^{2}$ & RMSE \\
\hline Dry clas & 10.50 & 0.41 & 1045.80 & $6.10 \pm 1.46$ & $6.11 \pm 0.74$ & 0.27 & 1.28 \\
\hline Intermediate & 12.08 & 0.52 & 851.30 & $8.56 \pm 3.35$ & $8.62 \pm 1.64$ & 0.33 & 2.76 \\
\hline Wet class & 8.15 & 1.24 & 598.80 & $8.92 \pm 3.59$ & $8.70 \pm 0.69$ & 0.03 & 3.52 \\
\hline Whole period & 10.84 & 0.63 & 316.80 & $8.43 \pm 3.40$ & $8.33 \pm 1.25$ & 0.17 & 3.12 \\
\hline
\end{tabular}

Amazon forest

F. B. Zanchi et al.

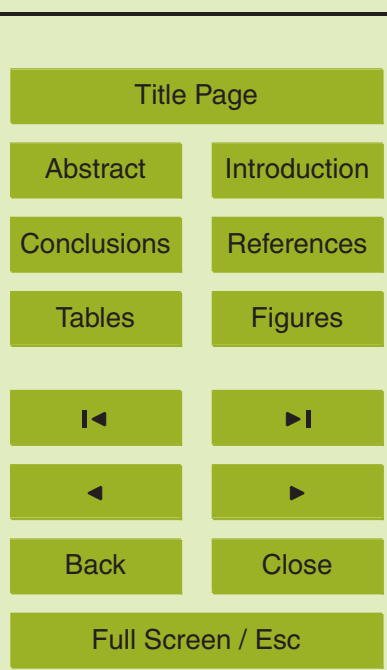

Printer-friendly Version

Interactive Discussion 


\section{BGD}

6, 6147-6177, 2009

Soil respiration and simple models in Amazon forest

Table 2. Model results from different average time and the Statistics of Eqs. (2), (4) and (9).

F. B. Zanchi et al.

\begin{tabular}{llllllll}
\hline Average period & \multicolumn{2}{c}{ Log model } & \multicolumn{3}{c}{ Exponential model } & \multicolumn{2}{c}{ Reichstein model } \\
& $R^{2}$ & RMSE & $R^{2}$ & $Q_{10}$ & RMSE & $R^{2}$ & RMSE \\
\hline 1 day & 0.39 & 1.90 & 0.29 & 3.30 & 2.02 & 0.27 & 2.32 \\
5 days & 0.44 & 1.70 & 0.32 & 3.40 & 1.90 & 0.30 & 2.32 \\
7 days & 0.43 & 1.90 & 0.38 & 4.00 & 1.95 & 0.34 & 2.28 \\
10 days & 0.67 & 1.30 & 0.40 & 3.70 & 1.76 & 0.39 & 2.26 \\
14 days & 0.49 & 1.70 & 0.38 & 3.50 & 1.87 & 0.41 & 2.06 \\
21 days & 0.46 & 2.00 & 0.20 & 2.70 & 2.46 & 0.26 & 2.37 \\
30 days & 0.87 & 0.80 & 0.65 & 3.90 & 1.29 & 0.46 & 2.19 \\
\hline
\end{tabular}

Title Page

Abstract

Introduction

Conclusions

References

Tables

Figures

14

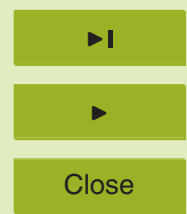

Back

Close

Full Screen / Esc

Printer-friendly Version

Interactive Discussion 
BGD

$6,6147-6177,2009$

Soil respiration and simple models in Amazon forest

\section{F. B. Zanchi et al.}

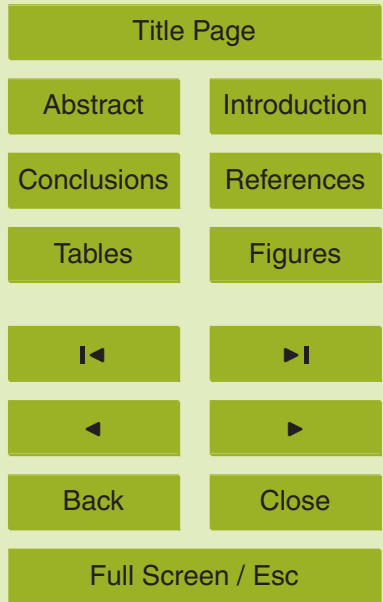

Fig. 1. Daily variation of soil respiration $\left(\mu \mathrm{mol} \mathrm{CO} \mathrm{Cm}^{-2} \mathrm{~s}^{-1}\right)$, soil temperature $\left({ }^{\circ} \mathrm{C}\right)$ and precipitation $(\mathrm{mm}$ ) for the dry period (28 July 2003 to 1 August 2003) and wet period (25-30 December Full Screen / Esc

Printer-friendly Version 
BGD

6, 6147-6177, 2009

Soil respiration and simple models in Amazon forest

\section{F. B. Zanchi et al.}

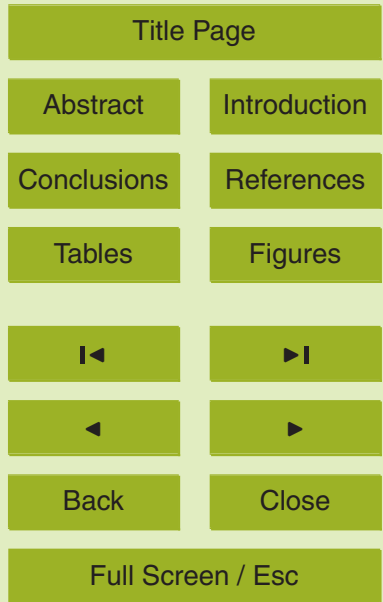

Fig. 2. Mean half-hourly data of (a) soil temperature $\left({ }^{\circ} \mathrm{C}\right)$, (b) soil respiration $\left(\mu \mathrm{mol} \mathrm{CO}_{2} \mathrm{~m}^{-2} \mathrm{~s}^{-1}\right)$ Full Screen / Esc

Printer-friendly Version

Interactive Discussion 
BGD

6, 6147-6177, 2009

\section{Soil respiration and} simple models in Amazon forest

\section{F. B. Zanchi et al.}

\section{Title Page}

Abstract

Introduction

Conclusions

References

Tables

Figures

I

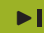

4

Back

Close

\section{Full Screen / Esc}

Printer-friendly Version

Interactive Discussion 


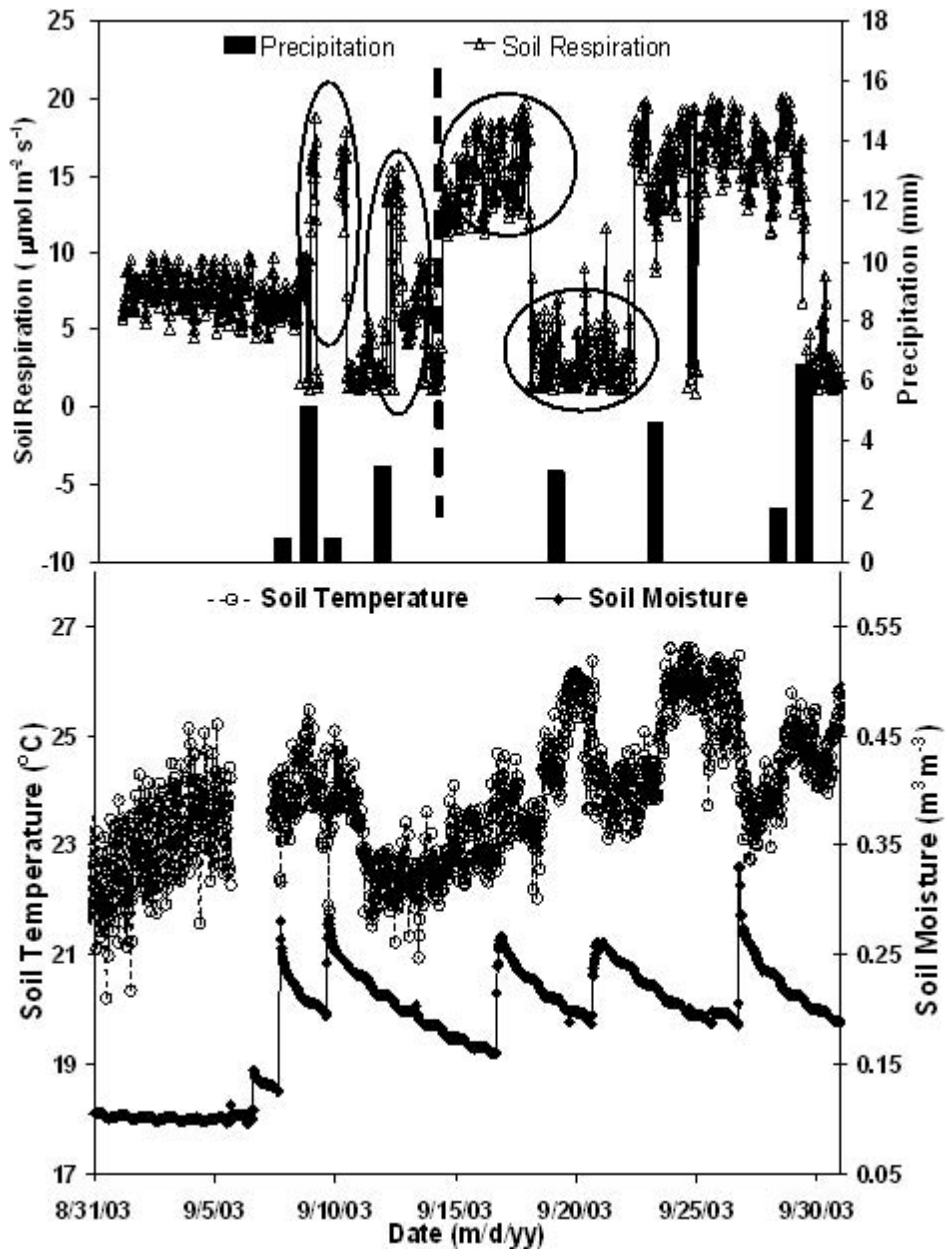

BGD

$6,6147-6177,2009$

Soil respiration and simple models in Amazon forest

F. B. Zanchi et al.

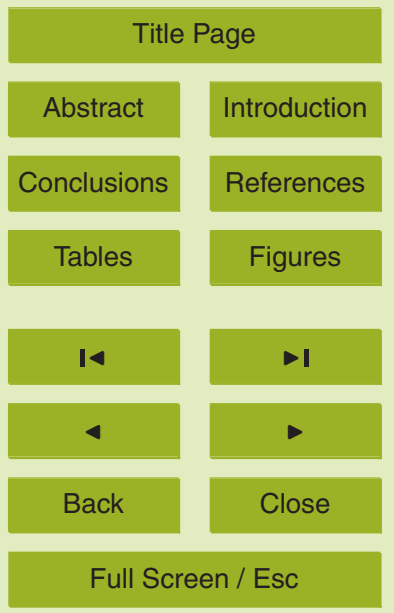

Printer-friendly Version

Interactive Discussion

Fig. 4. Variation of half-hourly soil respiration $\left(\mu \mathrm{mol} \mathrm{CO}_{2} \mathrm{~m}^{-2} \mathrm{~s}^{-1}\right)$ and precipitation $(\mathrm{mm})$ during the early wet season (3 September 2003 to 30 March 2003). 

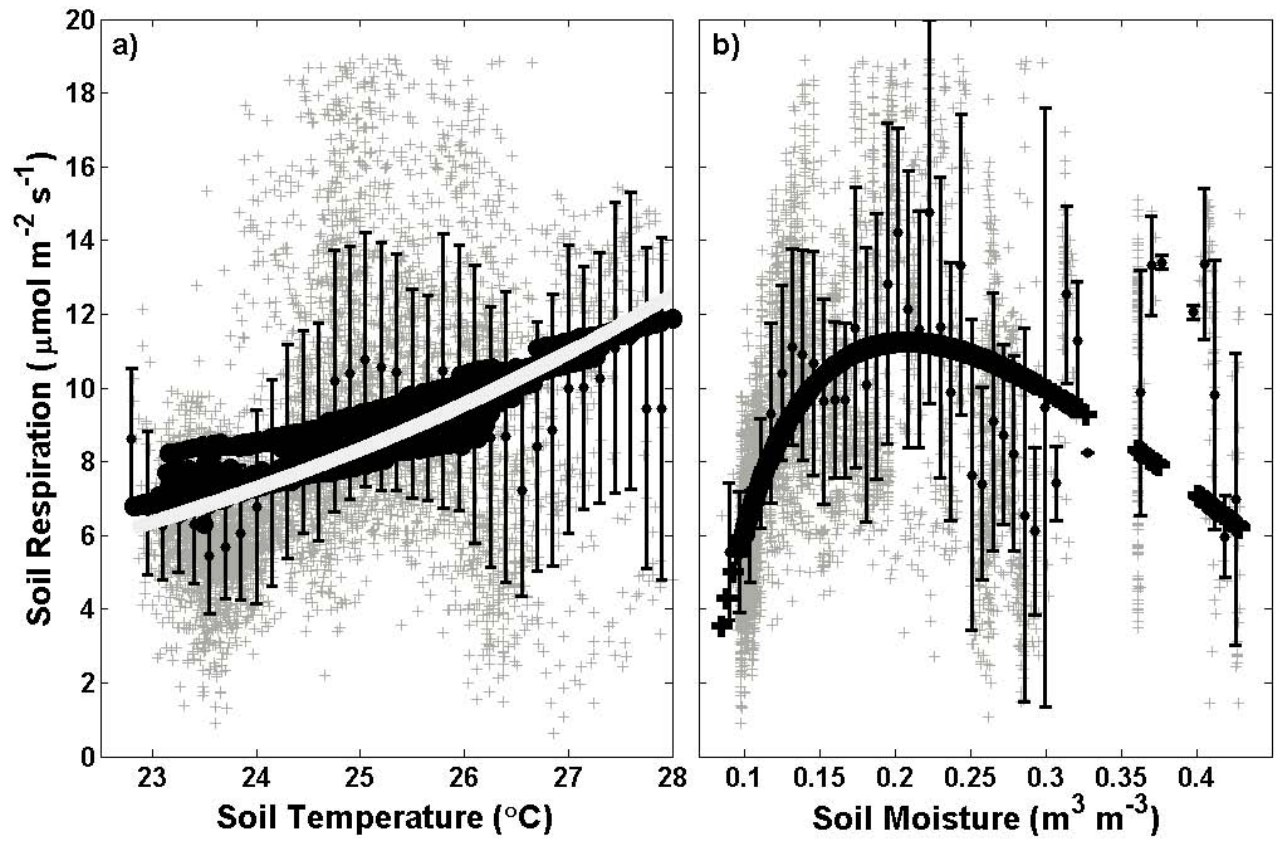

$6,6147-6177,2009$

Soil respiration and simple models in Amazon forest

F. B. Zanchi et al.

Fig. 5. Mean half-hourly (grey circle) and the standard deviation (black bars) of the soil respiration $\left(\mu \mathrm{mol} \mathrm{CO} \mathrm{CO}^{-2} \mathrm{~s}^{-1}\right)$ related to the soil temperature $\left({ }^{\circ} \mathrm{C}\right)$ and soil moisture $\left(\mathrm{m}^{3} \mathrm{~m}^{-3}\right)$. (a) Two models dependence of soil respiration with the soil temperature $\left({ }^{\circ} \mathrm{C}\right)$, where the Reichstein model (Scatter black line) had a $R^{2}=0.17$ and the RMSE $=3.12$ and the $Q_{10}$ Model (Solid grey line) had a $R^{2}=0.17, \mathrm{RMSE}=3.11$ and the $Q_{10}=3.9$ and (b) One model dependence of soil respiration with the soil moisture $\left(\mathrm{m}^{3} \mathrm{~m}^{-3}\right)$, where the log-soil moisture models (Solid black line) had a $R^{2}=0.31$ and $\mathrm{RMSE}=2.81$.

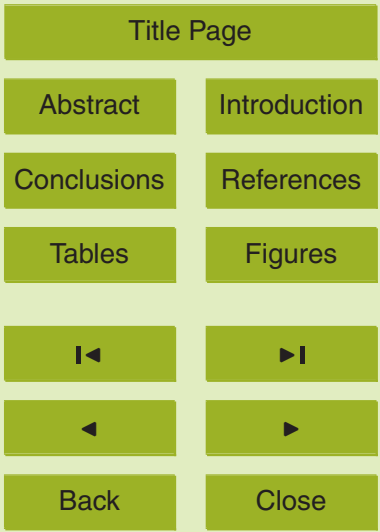

Full Screen / Esc

Printer-friendly Version

Interactive Discussion 


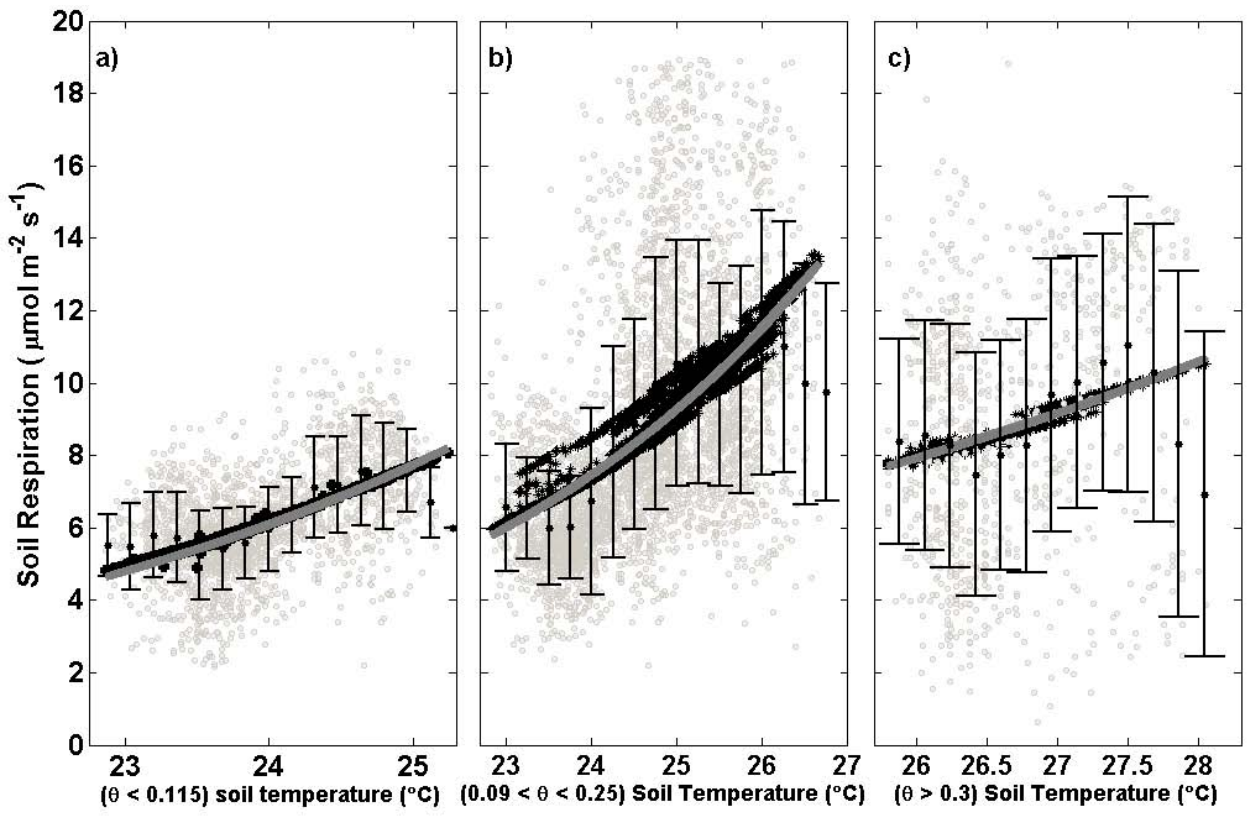

Fig. 6. Mean half-hourly (grey circle) and the standard deviation of soil respiration $\left(\mu \mathrm{mol} \mathrm{CO} \mathrm{Cm}^{-2} \mathrm{~s}^{-1}\right)$ and soil temperature $\left({ }^{\circ} \mathrm{C}\right)$, for specific classes of soil moisture and the models Reichstein (Scatter black lines) and the $Q_{10}$ Exponential (Solid grey line), namely: (a) $\theta \leq 0.115 \mathrm{~m}^{3} \mathrm{~m}^{-3}$, founding for Reichstein model a $R^{2}=0.27$ and the RMSE $=1.26$ and the $Q_{10}$ model a $R^{2}=0.26$, RMSE $=1.3$ and the $Q_{10}=11$; (b) $0.115<\theta \leq 0.25 \mathrm{~m}^{3} \mathrm{~m}^{-3}$, founding for the Reichstein model a $R^{2}=0.33$ and the RMSE $=2.76$ and the $Q_{10}$ model a $R^{2}=0.25$, RMSE $=2.91$ and the $Q_{10}=8.8$, and (c) $\left(\theta>0.3 \mathrm{~m}^{3} \mathrm{~m}^{-3}\right)$, founding for the Reichstein model a $R^{2}=0.03$ and the $\mathrm{RMSE}=3.5$ and the $Q_{10}$ model a $R^{2}=0.04, \mathrm{RMSE}=3.5$ and the $Q_{10}=4.3$.
BGD

$6,6147-6177,2009$

Soil respiration and simple models in

Amazon forest

F. B. Zanchi et al.

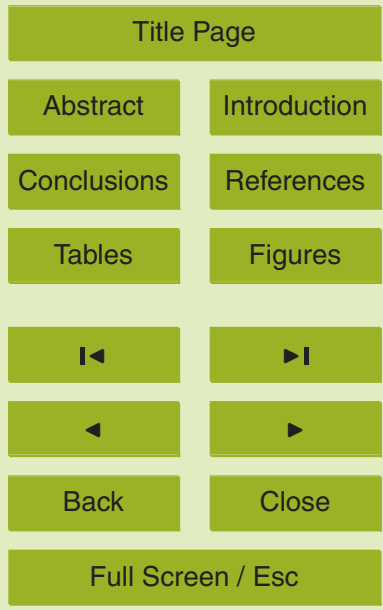

Printer-friendly Version

Interactive Discussion 
BGD

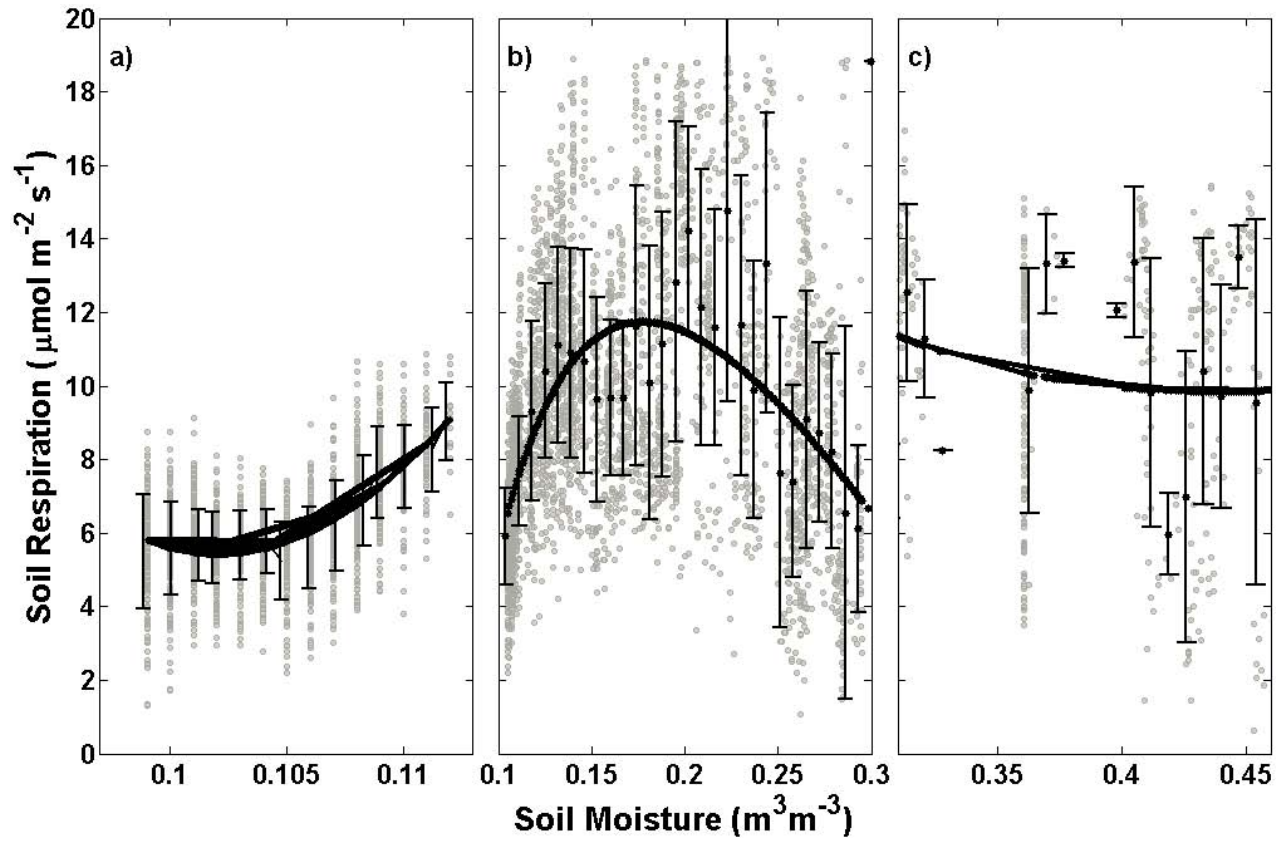

Fig. 7. Mean half-hourly (grey circle) and the standard deviation of soil respiration $\left(\mu \mathrm{mol} \mathrm{CO} \mathrm{m}^{-2} \mathrm{~s}^{-1}\right)$ and soil moisture $\left(\mathrm{m}^{3} \mathrm{~m}^{-3}\right)$, for specific classes of soil moisture using the log-soil moisture models (solid back line), namely: (a) $\theta \leq 0.115 \mathrm{~m}^{3} \mathrm{~m}^{-3}$, where the $R^{2}=0.36$ and the RMSE=1.2; (b) $0.115<\theta \leq 0.25 \mathrm{~m}^{3} \mathrm{~m}^{-3}$, where the $R^{2}=0.28$ and the RMSE $=2.89$ and (c) $\left(\theta>0.3 \mathrm{~m}^{3} \mathrm{~m}^{-3}\right)$, where $R^{2}=0.01$ and the RMSE $=3.5$.
$6,6147-6177,2009$

Soil respiration and simple models in Amazon forest

\section{F. B. Zanchi et al.}

\section{Title Page}

Abstract Introduction

Conclusions

References

Tables

Figures

14

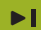

4

Back

Close

\section{Full Screen / Esc}

Printer-friendly Version

Interactive Discussion 


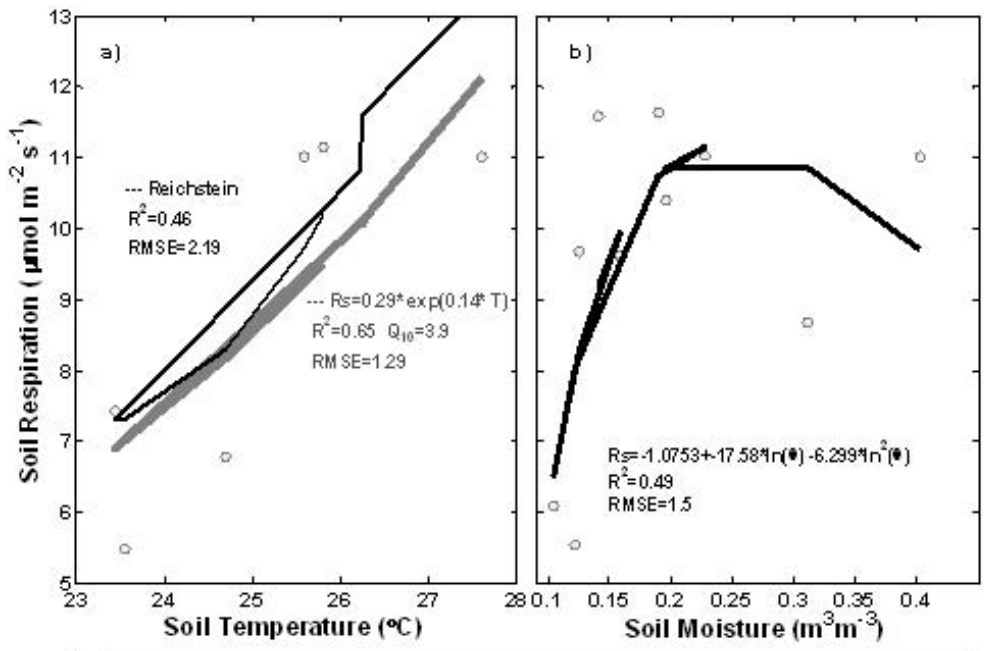

BGD

6, 6147-6177, 2009

Soil respiration and simple models in Amazon forest

F. B. Zanchi et al.

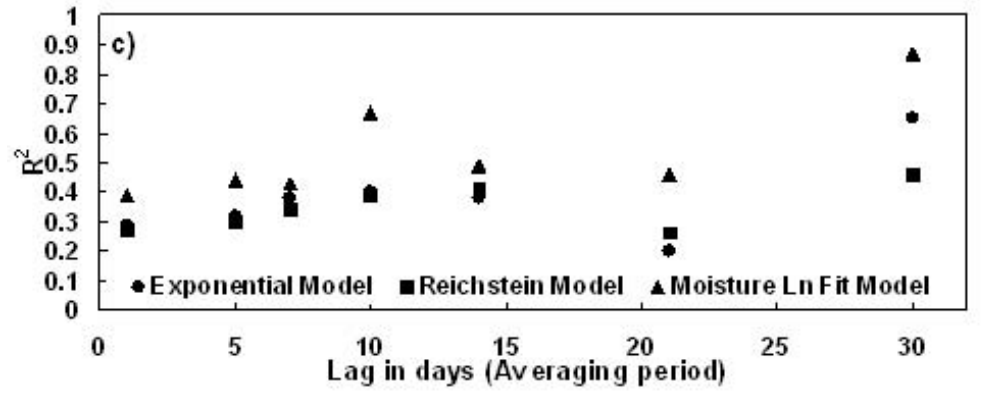

Title Page

Abstract

Introduction

Conclusions

References

Tables

Figures

14

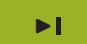

4

Back

Close

Full Screen / Esc

Fig. 8. Mean monthly soil respiration $\left(\mu \mathrm{mol} \mathrm{CO} \mathrm{C}^{-2} \mathrm{~s}^{-1}\right)$ and (a) soil temperature $\left({ }^{\circ} \mathrm{C}\right)$, (b) soil moisture $\left(\mathrm{m}^{3} \mathrm{~m}^{-3}\right)$ for all period; (c) Calculated the Lag days of the regression coefficient $R^{2}$ for the fitting between mean soil respiration averaged over a variable period (abscissa, in days),

Printer-friendly Version for the Reichstein, $Q_{10}$ Exponential, and log-soil moisture models, respectively.

Interactive Discussion 